\title{
Influence of Various Antioxidants on Microscopic-Oxidative Stress Indicators and Fertilizing Ability of Frozen-Thawed Bull Semen
}

\author{
Serpil Sariözkan ${ }^{1}$, Pürhan Barbaros Tuncer ${ }^{1}$, Mustafa Numan Bucak ${ }^{1}$, \\ Pınar Alkım Ulutaş² \\ ${ }^{1}$ Ministry of Agriculture and Rural Affairs, Lalahan Livestock Central Research Institute, \\ Lalahan, Ankara, Turkey, ${ }^{2}$ Adnan Menderes University, Faculty of Veterinary Medicine, Department of \\ Biochemistry, Aydın, Turkey
}

Received July 17, 2008

Accepted March 9, 2009

\begin{abstract}
Cryopreservation is associated with the production of reactive oxygen substances (ROS), which lead to lipid peroxidation of sperm membranes, resulting in a loss of sperm motility, viability and fertility. The aim of this study was to determine effects of the antioxidants of oxidized glutathione (GSSG), reduced glutathione (GSH) and bovine serum albumin (BSA) on standard semen indicators (motility, acrosome and total abnormalities, HOST), endogenous antioxidant enzyme activities and fertilizing ability of frozen-thawed bull semen.

Eighteen ejaculates from each of 3 Holstein bulls were collected using an artificial vagina and 9 replicates of the ejaculates were diluted with a Bioxcell ${ }^{\circledR}$-based extender supplemented with antioxidants, including BSA (5 mg/ml), GSH (2 mM), GGSG (2 mM), and an extender containing no antioxidants (control). Insemination doses $\left(1.5 \times 10^{7}\right.$ sperm $/ 0.25 \mathrm{ml}$ straw) were prepared for the insemination of cows at observed oestrus. Supplementation with antioxidants led to lower percentages of acrosome damage $(4.0 \pm 0.5 \%, 4.4 \pm 0.5 \%, 4.0 \pm 0.3 \%$, respectively) and total abnormalities $(10.3 \pm 0.7 \%, 9.7 \pm 0.8 \%, 10.4 \pm 0.6 \%)$, compared to the controls $(6.5 \pm 0.6$ and $14.9 \pm 1.1 \% P<0.01)$. Pregnancy rate after insemination was highest $(72.2 \%)$ in the group which was given BSA $(P<0.05)$. There were no significant differences among groups in GSH and glutathione peroxidase (GSH-PX) enzyme activities. Superoxide dismutase (SOD) activities $(0.05 \pm 0.005,0.03 \pm 0.005,0.05 \pm 0.009 \mu \mathrm{kat} / \mathrm{g}$ protein, respectively) in all of the experimental groups with antioxidants were lower than the control group $(0.11 \pm 0.024 \mu \mathrm{kat} / \mathrm{g}$ protein, $P<$ $0.001)$. Furthermore, BSA increased $(P<0.001)$ the activity of catalase (CAT, 304.23 \pm 114.69 $\mu \mathrm{kat} / \mathrm{g}$ protein), following the freezing-thawing process.
\end{abstract}

Bull semen, freezing, artificial insemination, antioxidant activities, lipid peroxidation

Semen cryopreservation has allowed specific opportunities for the conservation and widespread dissemination of valuable genetic resources through sperm banks, the guarantee of a constant commercial supply of semen, and collaboration in breed improvement programs by means of artificial insemination (AI) (Holt et al. 1997). Some of the problems encountered using AI in pigs, sheep and exotic species include decreased motility, membrane integrity and fertilizing potential of spermatozoa during cryopreservation, premature activation in the female genital tract, and altered membrane responses to physiological stimuli of sperm that survive the freezing-thawing process (Viswanath and Shannon 2000). It is well known that phospholipids in the sperm plasma membrane undergo peroxidation, which results in the formation of reactive oxygen substances (ROS, namely, superoxide anion radical, hydrogen peroxide) and lipid hydroperoxides (Alvarez and Storey 2005). Excessive generation of ROS by immature and abnormal spermatozoa, and sperm processing (e.g., extending, freezingthawing process), accompanied by low scavenging and antioxidant concentrations in seminal plasma and semen extender will induce oxidative stress (Sikka 2004). According to Trinchero et al. (1990), frozen-thawed bull spermatozoa are more easily peroxidized than fresh spermatozoa. Additionally, cryopreservation of bull semen has

Address for correspondence:

Dr. Serpil Sariozkan, DVM, PhD

Ministry of Agriculture and Rural Affairs

Lalahan Livestock Central Research Institute

Lalahan, Ankara, Turkey
Phone: $+903128651196 / 190$

Fax: +903128651112

E-mail: sariozkan75@yahoo.com

http://www.vfu.cz/acta-vet/actavet.htm 
been shown to decrease sperm intracellular antioxidants such as GSH and superoxide dismutase (SOD).

The antioxidant system comprising GSH, GSH-PX, catalase (CAT), and SOD has been described as a defense functioning mechanism against the lipid peroxidation (LPO) of semen, and is important in maintaining sperm motility and viability (Gadea et al. 2004). This antioxidant capacity in sperm cells may, however, be insufficient in preventing LPO during the freeze-thawing process. In that regard, mammalian spermatozoa lack a substantial cytoplasmic component, which contains antioxidants that counteract the damaging effects of ROS and LPO (Peris et al. 2007). Thiols such as GSH and GSSG are a large class of antioxidants. It is well known that GSH is able to react with many ROS directly and is a co-factor for GSH-PX which catalyses the reduction of toxic $\mathrm{H}_{2} \mathrm{O}_{2}$ and hydroperoxides (Bilodeau et al. 2001). The oxidized form of glutathione, GSSG, is partially regenerated from GSH by the action of the enzyme glutathione reductase, and secreted from the cell when the capacity of glutathione reductase is exceeded (Meister 1994). Mammalian cells can only utilize thiol compounds such as reduced and oxidized glutathione, which have been shown to penetrate the cell membrane easily, enhancing intracellular glutathione biosynthesis both in vitro and in vivo, and protecting the membrane lipids and proteins by direct radical-scavenging properties (Sagara et al. 1993; Mazor et al. 1996). Furthermore, bovine serum albumin (BSA) is known to protect sperm motility and the integrity of the plasma membrane and acrosome against temperature shock during the freezing-thawing process. It may also help sperm in surviving in the reproductive tract of the cow prior to fertilization (Chen et al. 1993; Uysal and Bucak 2007).

\section{Materials and Methods}

Animals and semen collection

Semen samples from three Holstein bulls, aged 3-4 years, from the Artificial Insemination Station belonging to Lalahan Livestock Central Research Institute (Ankara, Turkey) were used in this study. In total 66 ejaculates were collected twice weekly from the bulls with the aid of an artificial vagina. Only ejaculates containing spermatozoa with $>80 \%$ forward progressive motility and concentrations higher than $1.0 \times 10^{9}$ spermatozoa $/ \mathrm{ml}$ were used. Eighteen ejaculates for each bull were included in the study. The first and second ejaculates from the same bull were combined. Immediately after collection, the ejaculates were immersed in a warm water bath at $34{ }^{\circ} \mathrm{C}$ until their assessment in the laboratory. Semen assessment was performed in approximately 20 min. The study was replicated nine times.

\section{Semen processing and evaluation}

The antioxidants used in this study, including BSA (A9647), GSH (G6013), and GGSG (G2140) were obtained from Sigma-Aldrich chemicals, and Bioxcell ${ }^{\mathbb{Q}}$ extender was purchased from IMV Technologies (Şark Kemikal Ltd., Istanbul, Turkey). The volume of ejaculates was measured in a conical tube ( $0.1 \mathrm{ml}$ graduations $)$ and sperm concentration was determined with an Accucell photometer (IMV, L'Aigle, France). Sperm motility was estimated using phase contrast microscopy $(\times 200)$. A commercial extender $\left(\right.$ Bioxcell $\left.^{\mathbb{R}}\right)$ was used as the base freezing extender. Each ejaculate was split into four equal experimental groups and diluted to a final concentration of $6.0 \times 10^{7} / \mathrm{ml}$ spermatozoa, with the base extender containing BSA ( $\left.5 \mathrm{mg} / \mathrm{ml}\right)$, GSH $(2 \mathrm{mM})$, GGSG $(2 \mathrm{mM})$ and no antioxidants (control). These antioxidants were added directly to the base extender. Diluted semen samples were loaded into $0.25-\mathrm{ml}$ French straws and cooled to $4{ }^{\circ} \mathrm{C}$ in $2 \mathrm{~h}$, frozen at a programmed rate of $3{ }^{\circ} \mathrm{C} / \mathrm{min}$ from +4 to $-10{ }^{\circ} \mathrm{C} ; 40{ }^{\circ} \mathrm{C} / \mathrm{min}$ from -10 to $-100{ }^{\circ} \mathrm{C} ; 20{ }^{\circ} \mathrm{C} / \mathrm{min}$ from -100 to $-140{ }^{\circ} \mathrm{C}$ in a digital freezing machine (Digitcool $5300 \mathrm{ZB} 250$, IMV, France). Thereafter, the straws were plunged into liquid nitrogen $\left(-196{ }^{\circ} \mathrm{C}\right)$. After $24 \mathrm{~h}$, frozen straws were thawed in a $37^{\circ} \mathrm{C}$ water bath for $20 \mathrm{~s}$, immediately before use.

Progressive motility was assessed using a phase-contrast microscope $(\times 200$ magnification $)$, with a warm stage maintained at $37^{\circ} \mathrm{C}$. A wet mount was made using a 5- $\mu 1$ drop of semen placed directly on a microscope slide and covered by a cover slip. Sperm-motility estimations were performed in three microscopic fields for each semen sample. The mean of the three successive estimations was recorded as the final motility score (Bearden and Fuquay 2000).

For evaluation of sperm abnormalities, at least three drops of each sample were added to Eppendorf tubes containing $1 \mathrm{ml}$ of Hancock solution (62.5 ml formalin (37\%), $150 \mathrm{ml}$ sodium saline solution, $150 \mathrm{ml}$ buffer solution and $500 \mathrm{ml}$ double distilled water (Schafer and Holzman 2000). One drop of this mixture was put on a slide and covered with a cover slip. The percentages of acrosome and total abnormalities (acrosomal abnormality, detached heads, abnormal mid-pieces and tail defects) were determined by counting 400 spermatozoa under the phase-contrast microscopy $(\times 1000$ magnification, oil immersion $)$. 
The hypo-osmotic swelling test (HOST) was used to evaluate the functional integrity of the sperm membrane. This was performed by incubating $30 \mu \mathrm{l}$ of semen with $300 \mu \mathrm{l}$ of a $100 \mathrm{mOsm}$ hypo-osmotic solution at $37^{\circ} \mathrm{C}$ for $60 \mathrm{~min}$. After incubation, $0.2 \mathrm{ml}$ of the mixture was spread with a cover slip on a warm slide. Two hundred sperms were examined with a phase-contrast microscopy ( $\times 400$ magnification) and deemed to have either swollen or coiled tails (Bucket et al. 1997)

A total of 198 cows were artificially inseminated with frozen samples with antioxidants and control samples, each comprising semen from one bull. Each cow was artificially inseminated in the uterine body with $0.25 \mathrm{ml}$ of semen (total sperm dose of $1.5 \times 10^{7}$ sperm). Pregnancy rate was determined at 59 days post-insemination by transrectal palpation.

Biochemical assays were performed in sperm samples immediately after thawing and by centrifuging and washing. An aliquot $(500 \mu \mathrm{l})$ of semen from each sample was centrifuged at $800 \mathrm{~g}$ for $10 \mathrm{~min}$, and the sperm pellet was separated and washed by resuspending in PBS and recentrifuging (three times). After the last centrifugation, $1 \mathrm{ml}$ of deionized water was added to spermatozoa. The samples were thawed prior to the analyses for LPO and antioxidant enzyme activities (Dandekar et al. 2002).

The concentrations of malondialdehyde (MDA), as indices of LPO in sperm samples, were measured using the thiobarbituric acid reaction, in accordance with the method described by Yo shioka et al. (1979). The quantification of thiobarbituric acid-reactive substances was determined by comparing the absorption with the standard curve of malondialdehyde equivalents generated by the acid-catalyzed hydrolysis of 1,1,3,3-tetramethoxypropane. The MDA concentrations were measured as nmol/1.

The GSH content of sperm was measured using the method of Beutler et al. (1963). Samples were precipitated with $50 \%$ trichloracetic acid and centrifuged at $1000 \mathrm{~g}$ for $5 \mathrm{~min}$. The reaction mixture contained 2 $\mathrm{ml}$ of supernatant, $8 \mathrm{ml}$ phosphate buffer and $1 \mathrm{ml} \mathrm{DTNB}$ (55' dithiobis-2-nitrobenzoic acid). The solution was incubated at room temperature for $5 \mathrm{~min}$ and then read at $412 \mathrm{~nm}$ on a spectrophotometer. Values of GSH were expressed as nmol/1.

The GSH-PX activity was determined according to the method of Paglia and Valentine (1967). The reaction mixture contained $1 \mathrm{ml}$ phosphate buffer $(\mathrm{pH} 7), 100 \mu 13 \mathrm{mmol} / 1 \mathrm{NADPH}+\mathrm{H}, 100 \mu 110 \mathrm{mmol} / 1$ EDTA, 100 1 $20 \mathrm{mmol} / \mathrm{l} \mathrm{Na}$-azide, $100 \mu 120 \mathrm{mmol} / \mathrm{l}$ reduced glutathione, and $200 \mu \mathrm{l} 2 \mathrm{U}$ glutathione reductase. A $200-\mu 1$ sample was added to the above-mentioned mixture and this mixture was incubated for $3 \mathrm{~min}$ at $37^{\circ} \mathrm{C}$. The rate of GSSG formation was measured by following the decrease in the absorbance of the reaction mixture at $340 \mathrm{~nm}$, as NADPH was converted into NADP ${ }^{+}$, between the $2^{\text {nd }}$ and $4^{\text {th }}$ min after the initiation of the reaction, using a cuvette with a 1-cm light path. Calculations were based on a standard curve prepared with various concentrations of NADPH. The GSH-PX activity was expressed as nmol/NADPH/min $/ \mathrm{g}$ protein.

Determination of SOD was done as described by Sun and Zigman (1978). A mixture of $0.4 \mathrm{ml}$ sample, $0.1 \mathrm{ml}$ of $0.9 \% \mathrm{NaCl}$ and $0.4 \mathrm{ml}$ of chloroform: ethanol (3:5) was centrifuged for $10 \mathrm{~min}$ at $2000 \mathrm{~g}$. The reaction mixture contained $20 \mathrm{ml} 3 \mathrm{mmol} / 1$ xanthine, $10 \mathrm{ml} 0.6 \mathrm{mmol} / 1$ EDTA, $10 \mathrm{ml} 0.15 \mathrm{mmol} / 1 \mathrm{NBT}, 6 \mathrm{ml} 400 \mathrm{mmol} / 1 \mathrm{sodium}$ carbonate, and $3 \mathrm{ml} 1 \mathrm{~g} / \mathrm{l} \mathrm{BSA}$ for 20 tests. An aliquot $(50 \mu \mathrm{l})$ of xanthine oxidase $(20 \mu \mathrm{mol} / 2 \mathrm{ml})$ was added to $2.45 \mathrm{ml}$ of the reaction mixture and this mixture was incubated at $25{ }^{\circ} \mathrm{C}$ for $20 \mathrm{~min}$. Subsequently, the reaction was stopped by adding $1 \mathrm{ml}$ of $0.8 \mathrm{mmol} / 1 \mathrm{CuCl}_{2}$. Absorbance was recorded at $560 \mathrm{~nm}$ in a spectrophotometer, with SOD activity expressed as as $\mu \mathrm{kat} / \mathrm{g}$ protein.

The method described by Goth (1991) was used for the determination of CAT activity in sperm samples. Aliquots $(0.2-\mathrm{ml})$ of sperm samples were incubated in $1 \mathrm{ml}$ substrate $(65 \mathrm{mmol} / \mathrm{ml})$ hydrogenperoxide in 60 $\mathrm{mmol} / 1$ sodium-potassium phosphate buffer ( $\mathrm{pH}: 7.4)$ at $37^{\circ} \mathrm{C}$ for $60 \mathrm{~s}$. Under these conditions, one unit of CAT decomposes $1 \mu \mathrm{mol}$ of hydrogenperoxide per min. The enzymatic reaction was terminated with $1 \mathrm{ml}$ of 32.4 $\mathrm{mmol} / \mathrm{l}$ ammonium molybdate and hydrogen peroxide was measured at $405 \mathrm{~nm}$ using a spectrophotometer. Values of CAT activity were expressed as $\mu \mathrm{kat} / \mathrm{g}$ protein.

\section{Statistical analysis}

The study was replicated nine times. Values of semen characteristics, including motility, acrosome abnormality, total abnormalities and HOST were transformed to the arcsin scale to minimize heterogeneity of data. Results were expressed as mean \pm SEM. Means were analyzed by one-way analyses of variance, followed by Tukey's post-hoc test to determine significant differences between groups. In the analysis, to avoid inflating the degrees of freedom, account was taken of ejaculates nested within bulls. All analyses were conducted using the SPSS/ PC computer programme (Version 12.0, SPSS, Chicago, IL, USA). Differences with values of $P<0.05$ were considered significant. Pregnancy rates were evaluated with chi-square test.

\section{Results}

Semen characteristics of frozen-thawed bull semen are shown in Table 1. Antioxidants maintained post-thaw sperm morphology and acrosome integrity $(P<0.01)$ compared to the control group. However, there were no significant differences in membrane integrity and post-thaw sperm motility following the supplementation of the freezing extender with antioxidants. 
Table 1. Percentages of motility, acrosome, total abnormalities and HOST in frozen-thawed bull spermatozoa (means $\% \pm \mathrm{SEM}$ )

\begin{tabular}{|l|c|c|c|c|}
\hline Group & Motility & Acrosome abnormality & Total abnormalities & HOST \\
\hline BSA & $44.07 \pm 2.98^{\mathrm{a}}$ & $4.00 \pm 0.47^{\mathrm{a}}$ & $10.30 \pm 0.69^{\mathrm{a}}$ & $47.00 \pm 2.20$ \\
\hline GSSG & $50.56 \pm 1.17^{\mathrm{ab}}$ & $4.41 \pm 0.49^{\mathrm{a}}$ & $9.74 \pm 0.83^{\mathrm{a}}$ & $45.52 \pm 1.78$ \\
\hline GSH & $52.59 \pm 1.61^{\mathrm{b}}$ & $4.00 \pm 0.32^{\mathrm{a}}$ & $10.41 \pm 0.57^{\mathrm{a}}$ & $46.59 \pm 1.62$ \\
\hline Control & $49.81 \pm 1.23^{\mathrm{ab}}$ & $6.52 \pm 0.57^{\mathrm{b}}$ & $14.93 \pm 1.07^{\mathrm{b}}$ & $43.70 \pm 1.96$ \\
\hline$P$ & $*$ & $* *$ & $* * *$ & - \\
\hline
\end{tabular}

Different superscripts (a and b) within the same column demonstrate significant differences

$(* P<0.05 ; * * P<0.01 ; * * * P<0.001)$

-: $P>0.05$

Pregnancy rates are shown in Table 2 . The addition of BSA $(5 \mathrm{mg} / \mathrm{ml})$ had a significant positive effect, more pronounced than the addition of GGSG and the control group in protecting the fertilizing ability of bull sperm $(P<0.05)$.

Table 2. Pregnancy rates 59-d after insemination with frozen-thawed bull semen

\begin{tabular}{|l|c|c|}
\hline Group & $\mathrm{n}$ & Pregnancy rate (\%) \\
\hline BSA & 54 & $72.2^{\mathrm{b}}(39 / 54)$ \\
\hline GSH & 38 & $68.4^{\mathrm{ab}}(26 / 38)$ \\
\hline GSSG & 47 & $53.2^{\mathrm{a}}(25 / 47)$ \\
\hline Control & 59 & $54.2^{\mathrm{a}}(32 / 59)$ \\
\hline
\end{tabular}

Different superscripts ( $a$ and $b$ ) within the same column demonstrate significant differences

$(P<0.05)$ $(P<0.001)$. The addition of BSA increased the activity of CAT, compared to the other treatments, following the freezing-thawing process $(P<0.001)$. There were no significant differences among groups GSH-PX and GSH enzyme activities $(P>0.05)$.

Table 3. Malondialdehyde (MDA), reduced glutathione (GSH), superoxide dismutase (SOD), glutathione peroxidase (GSH-Px), and catalase (CAT) levels in frozen-thawed bull semen

\begin{tabular}{|l|c|c|c|c|c|}
\hline Group & $\begin{array}{c}\text { MDA } \\
(\mathrm{nmol} / \mathrm{l})\end{array}$ & $\begin{array}{c}\mathrm{GSH} \\
(\mathrm{nmol} / \mathrm{l})\end{array}$ & $\begin{array}{c}\text { SOD } \\
(\mu \text { kat/g protein) }\end{array}$ & $\begin{array}{c}\text { GSH-PX } \\
(\mathrm{nmol} / \mathrm{NADPH} / \\
\text { min/g protein) }\end{array}$ & $\begin{array}{c}\text { CAT } \\
(\mu \text { kat/g protein) }\end{array}$ \\
\hline BSA & $1.88 \pm 0.45^{\mathrm{a}}$ & $1.39 \pm 0.24^{\mathrm{b}}$ & $0.05 \pm 0.005^{\mathrm{a}}$ & $3.90 \pm 1.17$ & $304.23 \pm 114.69^{\mathrm{b}}$ \\
\hline GSH & $1.37 \pm 0.21^{\mathrm{ab}}$ & $0.57 \pm 0.19^{\mathrm{b}}$ & $0.03 \pm 0.005^{\mathrm{a}}$ & $5.99 \pm 0.52$ & $165.53 \pm 28.84^{\mathrm{a}}$ \\
\hline GSSG & $2.43 \pm 0.25^{\mathrm{b}}$ & $1.19 \pm 0.14^{\mathrm{b}}$ & $0.05 \pm 0.009^{\mathrm{a}}$ & $3.25 \pm 1.15$ & $131.69 \pm 31.17^{\mathrm{a}}$ \\
\hline Control & $0.70 \pm 0.13^{\mathrm{a}}$ & $1.33 \pm 0.23^{\mathrm{b}}$ & $0.11 \pm 0.024^{\mathrm{b}}$ & $2.90 \pm 0.63$ & $104.02 \pm 26.34^{\mathrm{a}}$ \\
\hline$P$ & ${ }^{* *}$ & & $*_{* *}$ & - & $*_{* * *}$ \\
\hline
\end{tabular}

Different superscripts (a and b) within the same column demonstrate significant differences

$(* P<0.05 ; * * P<0.01 ; * * * P<0.001)$

-: $P>0.05$

\section{Discussion}

Cryopreservation causes irreversible damage to sperm organelles, and changes in membrane fluidity and enzymatic activity, associated with a reduction in sperm motility, viability and fertilizing ability (Alvarez and Storey 1989; Hammerstedt 1993). 
Glutathione (1-g-glutamyl-1-cysteinylglycine) is a tripeptide thiol compound that has many important functions in cell physiology and metabolism, including the protection of the cell from oxidative stress, synthesis of protein and DNA and gamete cell fertilization (NasrEsfahani and Johnson 1992). In cattle, BSA is found in reproductive tract fluids, and helps to preserve sperm motility and acrosome integrity during the semen freezing process (Yamashiro et al. 2006).

In the present study, GSH and GGSG had a slight promoting effect on sperm motility, while ROS increased. In terms of post-thaw motility, the current results agree with previous studies on boar (Gadea et al. 2004), bull (Bilodeau et al. 2001; Foote et al. 2002), and ram semen (Bucak et al. 2008), where no improvement was detected in sperm motility in the presence of GSH. However, motility was not affected by the formation of LPO. This was contradictory to studies in humans (de Lamirande and Gagnon 1992), mice (Baiardi et al. 1997), and horses (Baumber et al. 2000) where deterioration of sperm motility was observed in the precence of free radicals. However, our results seemed lower than the findings of Chatterjee et al. (2001), in that the addition of GGSG to the freezing extender reduced by $35 \%$ the loss of motility of spermatozoa undergoing a freezing-thawing cycle. These contradictory results may be due to the differences in extender composition and glutathione concentration. In this study, BSA $(5 \mathrm{mg} / \mathrm{ml})$ protected sperm morphology and fertilizing potential of bull spermatozoa, with a significant antioxidant property as a result of increased activity of CAT, against cryodamage after the freeze-thawing process.

The axosome and associated dense fibres of the middle pieces in sperm are covered by mitochondria that generate energy from intracellular stores of ATP. It is well established that ROS can induce axonemal and mitochondial damage, resulting in the immobilization of sperm (Aitken and Clarkson 1987; Peris et al. 2007). Based on the current results, it appeared that GSH, GSSG and BSA had protective effects on sperm morphological integrity of the head, middle and tail pieces, promoting axonemal and mitochondrial stability.

Sperm cells and seminal plasma contain ROS scavengers, including the enzymes SOD, GSH-PX and catalase, which convert superoxide $\left(\mathrm{O}_{2}^{-}\right)$and peroxide $\left(\mathrm{H}_{2} \mathrm{O}_{2}\right)$ radicals into $0_{2}$ and $\mathrm{H}_{2} 0$. SOD and catalase also remove $\left(\mathrm{O}_{2}{ }^{-}\right)$generated by NADPH-oxidase in living cells (Alvarez and Storey 1989; Jeulin et al. 1989). However, GSH-PX removes peroxyl radicals from various peroxides, including $\mathrm{H}_{2} \mathrm{O}_{2}$ to improve sperm motility (Irvine 1996). In this study, the addition of antioxidants did not prevent LPO or maintain GSH, SOD and GSH-PX levels. Only catalase activity was higher in the group with BSA, compared to the other groups.

Extending and freezing-thawing of semen leads to low antioxidant activity in the presence or absence of antioxidants. This may partly explain the lower fertility of frozenthawed semen in comparison to fresh semen (Bilodeau et al. 2000; 2001). In this study, the group supplemented with $5 \mathrm{mg} / \mathrm{ml} \mathrm{BSA}$ had significantly better pregnancy rates 59 days after insemination, compared to GGSG and control groups. This finding may be due to a higher CAT level compared to the other groups. The current results agree with a study previously conducted in the bull (Foote et al. 1993) with respect to the pregnancy rate in a group with BSA.

Further studies on the determination of oxidative stress, antioxidative capacity and fertility of bull semen following the freezing-thawing process are required to understand the physiological-biochemical changes that are important in semen freezing and in vivo/ in vitro fertilization. The use of certain antioxidants to achieve better results in terms of motility, membrane integrity and fertility potential of cryopreserved bull sperm, is still under discussion and requires further investigations. Further studies are needed to block the loss of motility and fertility of frozen semen with effective antioxidants.

In conclusion, the addition of various antioxidants to freezing media improved the characteristics of frozen-thawed bull semen. Compared to the controls, the antioxidants 
(GSH, GGSG, and BSA) provided a cryoprotective effect on the morphological integrity of frozen-thawed bull spermatozoa. Furthermore, BSA also improved pregnancy rates, as well as significantly elevating CAT activity.

\section{Vliv různých antioxidantů na mikroskopické oxidativní stresové ukazatele a fertilizační schopnosti semene býků po zmražení a rozmražení}

Kryoprezervace je spojená s produkcí reaktivních kyslíkových substancí (ROS), které vedou k lipoperoxidaci membrán spermií. Následkem je ztráta motility, životaschopnosti a fertility spermií. Cílem této studie bylo stanovit vlivy antioxidantů oxidovaného glutathionu (GSSG), redukovaného glutathionu (GSH) a bovinního sérového albuminu (BSA) na standardní indikátory kvality semene (pohyblivost spermií, abnormality akrozomální a celkové, HOST), aktivity endogenních antioxidačních enzymů a fertilizační schopnost semene po zmražení a tání.

Od tř́i býků plemene Holštýn byly odebráno celkem 18 ejakulátů za pomocí umělé vagíny a 9 paralelních vzorků ejakulátů bylo ředěno pomocí extenderu na bázi Bioxcell ${ }^{\circledR}$ s doplňkem antioxidantů včetně BSA $(5 \mathrm{mg} / \mathrm{ml})$, GSh $(2 \mathrm{mM})$, GGSG $(2 \mathrm{mM})$ a extenderu, který neobsahoval antioxidanty (kontrola). Inseminační dávky $\left(1,5 \times 10^{7}\right.$ spermií $/ 0,25$ $\mathrm{ml}$ ) byly připraveny $\mathrm{k}$ inseminaci krav při pozorovaném estru. Obohacení antioxidanty vedlo ke snížení procenta akrozomálních poškození $(4,0 \pm 0,5 \%, 4,4 \pm 0,5 \%, 4,0 \pm 0,3$ $\%$ a celkového poškození spermií $(10,3 \pm 0,7 \%, 9,7 \pm 0,8 \%, 10,4 \pm 0,6 \%)$ ve srovnání s kontrolami $(6,5 \pm 0,6$ a 14,9 $\pm 1,1 \%), P<0,01)$. Procento zabřeznutí bylo po inseminaci nejvyšší $(72,2 \%)$ ve skupině krav s př́́davkem BSA $(P<0,05)$. Mezi skupinami nebyly nalezeny signifikantní rozdíly v aktivitě enzymů GSH a GSH-peroxidázy (GSH-PX). Aktivita superoxid dismutázy (SOD) $(0,05 \pm 0,005,0,03 \pm 0,005$ a $0,05 \pm 0,09 \mu \mathrm{kat} / \mathrm{g})$ byla ve všech sledovaných skupinách s antioxidanty nižší než v kontrolní skupině $(0,11 \pm 0,024$ $\mu \mathrm{kat} / \mathrm{g}, P<0,001)$. A konečně př́́davek BSA zvýšil $(P<0,001)$ aktivitu katalázy (CAT $303,23 \pm 114,69 \mu \mathrm{kat} / \mathrm{g})$ po procesu zamražení a rozmražení ejakulátu.

\section{Acknowledgements}

The authors thank Dr. Ali Bilgen for the statistical analyses, and the staff of the Department of Artificial Insemination for their assistance.

\section{References}

Aitken RJ, Clarkson JS 1987: Cellular basis of defective sperm function and its association with the genesis of reactive oxygen species by human spermatozoa. J Reprod Fertil 81: 459- 469

Alvarez JG, Storey BT 1989: Role of glutathione peroxidase in protecting mammalian spermatozoa from loss of motility caused by spontaneous lipid peroxidation. Gamete Res 23: 77-90

Alvarez JG, Storey BT 2005: Differential incorporation of fatty acids into and peroxidative loss of fatty acids from phospholipids of human spermatozoa. Mol Reprod Dev 42: 334-346

Baiardi G, Ruiz RD, Cuneo M, Ponce AA, Lacuara JL, Vincenti L 1997: Differential effects of pharmacologically generated reactive oxygen species upon functional activity of epididymal mouse spermatozoa. Cancer J Physiol Pharmacol 75: 17533-17538

Baumber J, Ball BA, Gravance CG, Medina V, Davies-Morel MCG 2000: The effect of reactive oxygen species on equine sperm motility, viability, acrosomal integrity, mitochondrial potential and membrane lipid peroxidation. J Androl 21: 895-902

Bearden HJ, Fuquay JW 2000: Semen evaluation. In: BEARDEN HJ, FUQUAY JW (Ed.), Applied Animal Reproduction. New Jersey: Prentice Hall, Upper Saddle River, pp.168-182

Beutler E, Duban O, Kelly BM 1963: Improved method for the determination of blood glutathione. J Lab Clin Med 61: 882-888

Bilodeau JF, Blanchette S, Gagnon IC, Sirard MA 2001: Thiols prevent $\mathrm{H}_{2} \mathrm{O}_{2}$-mediated loss of sperm motility in cryopreserved bull semen. Theriogenology 56: 275-286

Bilodeau JF, Chatterjee S, Sirard MA, Gagnon C 2000: Levels of antioxidant defenses are decreased in bovine spermatozoa after a cycle of freezing and thawing. Mol Reprod Dev 55: 282-288

Bucak MN, Ateşşahin A, Yüce A 2008: Effect of anti-oxidants and oxidative stress parameters on ram semen after the freeze-thawing process. Small Rum Res 75: 128-134 
Buckett WM, Luchas MJ, Aird IA, Farquharson RG, Kingland CR, Lewis- Jones DI 1997: The hypo-osmotic swelling test in recurrent miscarriage. Fertil Steril 68: 506-509

Chatterjee S, De Lamirande E, Gagnon C 2001: Cryopreservation alters membrane sulfhydryl status of bull spermatozoa: protection by oxidized glutathione. Mol Reprod Dev 60: 498-506

Chen Y, Foote RH, Brockett CC 1993: Effect of sucrose, trehalose, hypotaurine, taurine, and blood serum on survival of frozen bull sperm. Cryobiology 30: 423-431

Dandekar SP, Nadkarni GD, Kulkarni VS, Punekar S 2002: Lipid peroxidation and antioxidant enzymes in male infertility. F Postgrad Med 48: 186-189

De Lamirande E, Gagnon C 1992: Reactive oxygen species and human spermatozoa. I. Effects on the motility of intact spermatozoa and on sperm axonemes. J Androl 13: 368-378

Foote RH, Brockett CC, Kaproth MT 2002: Motility and fertility of bull sperm in whole milk extender containing antioxidants. Anim Reprod Sci 71: 13-23

Foote RH, Chen Y, Brockett CC 1993: Physiology and management. Fertility of bull spermatozoa frozen in whole milk extender with trehalose, taurine, or blood serum. J Dairy Sci 76: 1908-1913

Gadea J, Selles E, Marco MA, Coy P, Matas C, Romar R, Ruiz S 2004: Decrease in glutathione content in boar sperm after cryopreservation. Effect of the addition of reduced glutathione to the freezing and thawing extenders. Theriogenology 62: 690-701

Goth LA 1991: A simple method for determination of serum catalase activity and revision of reference range. Clin Chim Acta 196: 143-152

Hammerstedt RH 1993: Maintenance of bioenergetic balance in sperm and prevention of lipid peroxidation: a review of the effect on design of storage preservation systems. Reprod Fertil 5: 675-690

Holt WV 1997: Alternative strategies for the long-term preservation of spermatozoa. Reprod Fertil Dev 9: 309319

Irvine DS 1996: Glutatione as a treatment for male infertility. Rev Reprod 1: 6-12

Jeulin C, Soufir JC, Weber P, Laval-Martin D, Calvayrac R 1989: Catalase activity in human spermatozoa and seminal plasma. Gamete Res 24: 185-196

Mazor D, Golan E, Philip V 1996: Red blood cell permeability to thiol compounds following oxidative stress. Eur J Haematol 57: 241-246

Meister A 1994: Glutathione, ascorbate and cellular protection. Cancer Res 54: 1969-1975

Nasr-Esfahani MH, Johnson MH 1992: Quantitative analysis of cellular glutathione in early preimplantation mouse embryos developing in vivo and in vitro. Hum Reprod 7: 1281-1290

Paglie DE, Valentine WN 1967: Studies on the qualitative and quantitative characterisation of erytrocyte glutathione peroxidase. J Lab Clin Med 70: 158-169

Peris IS, Bilodeau JF, Dufour M, Bailey J 2007: Impact of cryopreservation and reactive oxygen species on DNA integrity, lipid peroxidation, and functional parameters in ram semen. Mol Reprod Dev 74: 878-892

Sagara J, Miura K, Bannai S 1993: Cysteine uptake and glutathione level in fetal brain cells in primary culture and in suspension. J Neurochem 61: 1667-1671

Schafer S, Holzman A 2000: The use of transmigration and spermac stain to evaluate epididymal cat spermatozoa. Anim Reprod Sci 59: 201-211

Sikka SC 2004: Role of oxidative stress and antioxidants in andrology and assisted reproductive technology. J Androl 25: 5-18

Sun M, Zigman S 1978: Determination of superoxide dismutase in erythrocytes using the method of adrenaline autooxidation. Anal Biochem 90: 81-89

Trinchero GD, Affranchino MA, Schang LM, Beconi MT 1990: Antioxidant effect of bovine spermatozoa on lipid peroxidation. Com Biol 8: 339-350

Uysal O, Bucak MN 2007: Effect of oxidized glutathione, bovine serum albumin, cysteine and lycopene on the quality of frozen thawed ram semen. Acta Vet Brno 76: 383-390

Vishwanath R, Shannon P 2000: Storage of bovine semen in liquid and frozen state. Anim Reprod Sci 62: 23-53

Yamashiro H, Wang H, Yamashita Y, Kumamoto K, Terada T 2006: Enhanced freezability of goat spermatozoa collected into tubes containing extender supplemented with bovine serum albumin. J Reprod Dev 52: 407-414

Yoshioka T, Kawada K, Shimada S 1979: Lipid peroxidation in maternal and cord blood and protective mechanism against activated oxygene toxicity in the blood. Am J Obstet Gynecol 135: 372-376. 